\title{
К 90-ЛЕТИЮ ПРОФ. В. П. ТАРАНЕНКО
}

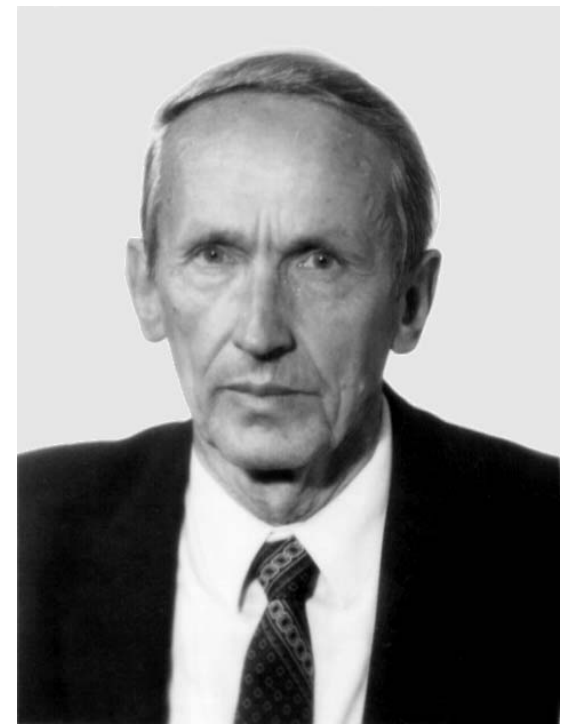

ТАРАНЕНКО Вадим Павлович в 1941 году закончил среднюю школу в г. Киеве. В 1949 г. закончил радиотехнический факультет Киевского политехнического института. После окончания аспирантуры и защиты кандидатской диссертации (1952 г.) работает в этом же вузе на должностях ассистента (1952-1954 гг.), доцента (1954-1959 гг.), заведующего кафедрой радиотехнических устройств и систем РТУС (1959-1998 гг.). Доктор технических наук, профессор с 1970 г. Декан радиотехнического факультета КПИ с 1974 до 1988 г.

Профессор Тараненко В.П. является известным ученым в области электроники сверхвысоких частот. Под его руководством разработаны и внедрены в производство первые в СССР мощные лампы бегущей волны, генераторы и усилители миллиметрового диапазона, которые нашли широкое применение в радио- локации, системах радиоэлектронного подавления и системах радиокоммуникаций. Научные разработки защищены 16 авторскими свидетельствами. Он является автором более 140 научных трудов, в том числе 2 монографий и одного учебного пособия. Им подготовлено 30 кандидатов и 4 доктора технических наук. Тараненко В.П. создал научную школу, завоевавшую большой авторитет как в родной стране, так и за рубежом.

Вадим Павлович - член международного Института Инженеров электриков и электронщиков (IEEE, 1992 г.), член редколлегии журнала «Известия ВУЗов. Радиоэлектроника» с 1959 г. Он был председателем экспертной комиссии по радиотехнике и электронике Минвуза Украины, членом научно-методической комиссии по радиотехнике при Госкомитете СССР по образованию, членом научных советов АН СССР по проблематике «Твердотельная электроника» и АН Украины по проблематике «Физика и техника миллиметровых волн».

Заслуги Вадима Павловича отмечены орденом Ленина и орденом «Знак Почета». Он Лауреат Государственной премии Украины в области науки и техники (1975 г.), Лауреат премии Совета министров СССР (1990 г.), Заслуженный деятель науки и техники Украины (1980 г.).

Коллеги, члены редколлегии, ученики, работники вузов и промышленности сердечно поздравляют Вадима Павловича с юбилеем и желают ему доброго здоровья, бодрости и душевной молодости на долгие годы жизни. 